\title{
PENGARUH TRADISI MACAPATAN SINDUJOYO TERHADAP PRILAKU MASYARAKAT DESA LUMPUR GRESIK
}

\author{
Akhmad Hamdani \\ Sekolah Tinggi IImu Tarbiyah (STIT) Raden Santri Gresik \\ Email. daniahdan09@gmail.com
}

\begin{abstract}
Abstrak
Macapat merupakan tradisi/seni membaca naskah kuno, adapun Macapat Sindujoyo merupakan tradisi membaca naskah kuno yang bercerita tentang pendahulunya yaitu bernama Sindujoyo yang sekarang dijadikan sebagai nama tempat, nama desa dan namanama yang lain. Tradisi Macapat Sindujoyo memiliki kekhasan tersendiri dibanding dengan Macapat yang ada di Nusantara yaitu Macapat ini khas dengan Macapat pesisir karena sebagian besar penduduk di Sindujoyo adalah nelayan. Berdasarkan pengumpulan data dalam penelitian skripsi ini dengan angket,, interview, dokumentasi dan observasi. Maka pengaruh tradisi Macapatan Sindujoyo terhadap prilaku masyarakat Lumpur Gresik mempunyai pengaruh yang sangat rendah, dapat dibuktikan dengan hasil angket dan interview 100 orang responden yang diperoleh hasil 0,189 yang memiliki pengaruh terhadap prilaku masyarakat Lumpur kecamatan Gresik Kabupaten Gresik.
\end{abstract}

\section{PENDAHULUAN}

Keberagaman kebudayaan dan adat istiadat di tiap-tiap daerah di Indonesia selalu bebeda dan beragam. Keberagaman tersebut menunjukkan akan kaya tanah air Indonesia, selain itu menunjukkan pluralitas bangsa. Salah satu yang menjadi manarik perhatian adalah kebudayaan di daerah Lumpur Kecamatan Gresik Kabupaten Gresik yang selalu menyelenggrakan tradisi Macapatan atau macapat Sindujoyo pada waktuwaktu tertentu. Macapatan merupaka suatu cerita atau manuskrip kuno yang dibaca dengan di Langgamkan atau berirama Cengkok. Tradisi macapatan tidak hanya ada di Gresik di beberapa daerah di Indonesia juga masih ada yang melestarikannya, sehingga cengkoknyapun beragam. Untuk wilayah Gresik cengkok Macapatan memiliki khas gaya Pesisiran. Hal demikian tidak lepas dari wilayah Gresik yang berada di daerah pesisir dan dikelilingi pelabuhan-pelabuhan besar.

Tradisi Macapatn Sindujoyo merupakan salah satu jenis sastra yang mulai langka. Tradisi Macapatan semacam ini jarang dijumpai di kota-kota besar. Seperti pendapat Wellek bahwa semua karya seni "manis" dan sekaligus "bermanfaat" bagi setiap penikmatnya. Sesuai dengan sifatnya kesenangan dan manfaat bukan hanya 
harus ada melainkan harus saling mengisi ${ }^{1}$. Berdasarkan pendapat Wellek tersebut, tradisis Macapatan Sindujoyo mempunyai fungsi tertentu bagi penikmatnya. Maksud pembacaan naskah Macapatan Sindujoyo atau tradisi Macapatan Sindujoyo adalah agar keturunan Sindujoyo mengenal leluhurnya. Selain itu tradisi Macapatan Sindujoyo di maksudka untuk memberi ajaran kepada keturunan Sindujoyo agar memiliki prilaku utama, yaitu sikap dan tata kelakuan yang didasari budi luhur mereka, yaitu Sindujoyo.

Tradisi Macapat atau Macapatan di Gresik merupakan ajaran tentang budi luhur dan keagamaan yang disajikan dengan cara mendendangkan tembang-tembang Macapat. Hal demikian dimaksudkan agar isi ajaran dipahami dan diserap dengan senang hati. Selain untuk mencari berkah atas pembacaan naskah yang dianggap sakral tersebut. Tradisi macapatan Sindujoyo juga dimaksudkan untuk menghibur masyarakat sekitar dan mengalihkan kebiasaan pemuda yang kurang baik menjadi kegiatan yang lebih bermanfaat.

Tradisi Macapatan Sindujoyo ini dilaksanakan pada waktu-waktu tertentu, yaitu pada saat haul (satu tahun) Sindujoyo, pesta rakyat, atau pada malam acara ngantenan (pesta perkawinan) Tradisi Macapat atau Macapatan dapat diilustrasikan bahwa pembaca menyampaikan ceritanya dengan cara membaca naskah Macapat Sindujoyo. Pembaca naskah macapat duduk dan pendengarnya bersama-sama ikut membaca manuskrip Macapat tersebut.

Keberadaan manuskrip macapat sudah sangat langkah dan menjadi manuskrip yang dilindungi oleh masyarakat Sindujoyo, sehingga harus disimpan ditempat yang aman dan dengan perawatan yang tidak mudah agar manuskrip tersebut tidak rusak. Adapaun masyarakat sekitar yang ingin membacanya mereka dapat membaca hasil penggandaan atau fotocopy. Adapun keberadaan naskahMacapat Sindujoyo di simpan makam dalam yang dikenal dengan sebutan Makam Dalem Kelurahan Karangpoh Kecamatan Gresik Kabupaten Gresik, agar terjaga dan tidak rusak.

Karena konten atau isi macapat yang bermuatan kebaikan-kebaikan kehidupan manusia maka penulis terterik untuk meneliti dan menulisnya dalam artikel ilmiyah. Maka judul yang tepat adalah "Pengaruh Tradisi Macapatan Sindujoyo Terhadap Prilaku Masyarakat Lumpur Kecamatan Gresik Kabupaten Gresik”

${ }^{1}$ Renne Wellek dan Austin Warren, Teori Kesusastraan, (Diterjemahkan Oleh Melani Budianta), hal. . (Jakarta: Gramedia, 1995), hal. 26-27 


\section{METODOLOGI PENELITIAN}

Penelitian ini dilakukan di Dusun Sindujoyo Kelurahan Lumpur Kecamatan Gresik Kabupaten Gresik. Adapun naskah Macapat yang bertuliskan huruf arab Pegon sebagai kajian dalam penelitihan ini. Jenis penelitian ini merupakan penelitian kuantitatif, oleh sebab itu peneliti harus menentukan populasi penelitian, populasi penelitian yang dimaksud merupakan subjek penelitian². Adapun populasi penelitian dalam penelitian ini adalah seluruh masyarakat lumpur Gresik kecamatan Gresik kabupaten Gresik yang berjumlah 5.150 jiwa. Langkah selanjutnya yaitu peneliti harus menentukan sampel penelitian dengan menyebutkan ciri-ciri tertentu masing-masing sampel. Masyarakat Sindujoyo yang berjumlah 5.150 jiwa maka akan diambil 100 orang sebagai sampel penelitian yang sesuai dengan kriteria yang telah ditentukan oleh peneliti sebelumnya.

Langkah selanjutnya yaitu peneliti menntukan metode pengumpulan data. Adapun metode yang digunakan adalah angket, dokumentasi, observasi, dan intervew. Metode angket digunakan untuk menggali informasi tentang pengaruh dan tanggapan terhadap pelaksanaan tradisi Macapatan Sindujoyo di kelurahan Lumpur Gresik. Metode dokumentasi digunakan untuk mencari dan menggali informasi terkait manuskrip Macapat Sindujoyo dan dokumentasi seperti foto-foto pelaksanaan Macapat. Etode observasi digunakan peneliti untuk mengamati prilaku dan kejadiankejadian yang ada di masyarakat yang masih ada hubungannya dengan Macapat. Sedangkan interview merupakan metode yang digunakan peneliti untuk mencari informasi dari masyarakat dan tokoh tentang tradisi Macapat dan prilaku masyarakat.

Analisa data merupakan rangkaian dari kegiatan penelitian yang dilakukan oleh peneliti setelah data terkumpul. Dalam penelitian proses data dimulai dengan merekam seluruh data yang diperoleh dari berbagai sumber yairu dari wawancara, pengamatan yang tertulis dalam catatan lapangan dan beberapa dokumen dari tokoh masyarakat dan masyarakat pada umumnya di desa Lumpur Sindujoyo. Oleh sebab itu peneliti dapat menganalisis dengan cara berpikir deduktif, yaitu cara berpikir yang berpijak pada fakta-fakta yang ada di lapangan secara umum, kemudian diteliti dan hasilnya dapat memecahkan masalah yang ada dalam penelitian. Cara berpikir ini digunakan peneliti untuk memecahkan masalah yang ada dirumusan masalah. Selain itu peneliti menggunakan cara berpikir induktif, yaitu peneliti melihat fakta-fakta yang

2Suharsimi Arikunto, Prosuder Penelitian Suatu Pendekatan Praktek. (Jakarta: PT. Rineka Cipta), hal 91 
bersifat khusus, selanjutnya diteliti dan hasilnya daharapkan dapat memecahkan persoalan secara umum.

Adapun data yang penulis peroleh dalam penelitian tentang "Pengaruh Tradisi Macapatan terhadap Prilaku Masyarakat Sindujoyo Lumpur Gresik" dapat penulis jabarkan bahwa untuk mendapatkan data yang diperoleh tentang pegetahuan masyarakat tentang tradsi Macapatan, yaitu dengan cara penulis menyebarkan angket kepada 100 responden yaitu $1,94 \%$ baik laki-laki maupun perempuan sebagai sampelnya dan masyarakat lumpur yang berjumlah 5.150 orang.

Adapun angket yang telah diberikan pada 100 orang tersebut merupakan pertanyaan-pertanyaan yang berbentuk multiple choice (pilihan ganda). Dalam narasi angket tersebut ada 10 pertanyaan dengan cara responden menjawab salah satu jawaban yang menurutnya dominan benar. Jawaban-jawaban yang disediakan oleh peneliti adalah jawaban yang mengarah pada pengetahuan masyarakat tentang tradisi Macapatan.

Penilaian angket penulis menggunakan landasan dalam memberikan skor masing-masing jawaban yaitu, 1) untuk jawaban A dengan nilai 3 2) untuk jawanban $B$ dengan nilai 2 3) untuk jawaban $C$ dengan nilai 1. Setelah penilaian angket dilakukan maka untuk menentukan pengetahuan masyarakat tentang Macapatan Sindujoyo dalam kategori pengetahuan yang, tinggi, sedang dan rendah. Maka peneliti membuat patokan atau standart pada penilaian tersebut yaitu:

- Untuk hasil nilai angket antara 12-18 penulis kelompokkan pada pengetahuan yang rendah

- Untuk hasil nilai angket antara 19-25 penulis kelompokkan pada pengetahuan yang sedang

- Untuk hasil nilai angket antara 26-32 penulis kelompokkan pada pengetahuan yang tinggi

Adapun untuk mendapatkan data tentang perubahan prilaku masyarakat Lumpur setelah mengikuti tradisi Macapatan Sindujoyo, penulis sengaja mengambil dari interview langsung kepada masyarakat Lumpur. Pertanyaan interview yang penulis susun sebanyak 8 pertanyaan yang ditersebar ke 100 responden dan penulis kategorikan jwabanawaban masyarakat menadi 3 pilihan $A, B$, dan C. Berdasarkan jawaban interview penulis mengkategorisasikan prilaku yang baik (B), kategorisasi prilaku cukup $(\mathrm{C})$ dan kategorisasi prilaku kurang $(\mathrm{K})$, maka dari sini penulis dapat menjumlahkan data pengaruh masyarakat dengan ketentuan: 
- Nilai B skornya 8

- Nilai C skornya 7

- Nilai K skornya 6

Setelah data prilaku masyarakat dijumlahkan dan diperoleh nilai maka penulis mengelompokkan prilaku masyarakat yaitu:

- Baik (B) jika dijumlahkan nilainya 63-70

- Cukup (C) jika dijumlahkan nilainya 55-62

- Kurang (K) jika dijumlahkan nilainya 47-54

\section{HASIL PENELITIAN DAN PEMBAHASAN}

\section{A. Konsep Nilai Budaya dalam Sebuah Tradisi}

Nilai adalah tujuan dari kehendak manusia. Nilai menjadi motivator utama dari tindakan manusia dari seluruh aspek yang mempengaruhi kompleksitas tindakan manusia. Nilai adalah sesuatu non material. Nilai dalam etika dikenal terutama nilai-nilai rohani, yaitu yang baik, yang benar, yang indah ${ }^{3}$. Memang tidak dengan gampang menjelaskan nilai karena wujudnya tidak dapat dilihat secara langsung, namun dapat dirasakan oleh manusia sebagai suatu kebaikan dan dapat memberikan dampak yang baik terdahap kehidupan manusia sebagai individu dan masyarakat.

Busro seperti yang dikutip oleh Sutarno menjelaskan tentang jenis-jenis nilai 1) Nilai Etika, yang menyangkut baik dan buruk prilaku manusia 2) Nilai estetika, berhubungan dengan keindahan 3) Nilai agama, berhubungan dengan perintah dan laangan tuhan 4) Nilai sosial, yang menyangkut hubungan antara manusia dengan pergaulan hidup. Sudikan menjelaskan bahwa nilai budaya adalah masalah dasar yang amat penting dan bernilai dalam kehidupan manusia yang dianggap dan diyakini sebagai suatu hal yang sangat berharga ${ }^{4}$. Oleh sebab itu nilai suatu budaya atau suatu kelompok tertentu atau bahkan komunitas tidak mudah untuk dirubah, dihilangkan atau dihapus dalam kehidupan sosial masyarakat yang sudah menjadi bagian kehidupan mereka. Bahkan nilai suatu budaya tersebut sudah turun temurun yang diwariskan oleh orang-orang terdahulu yang dinilai sebagai warisan budaya.

${ }^{3}$ Muhammad Yusuf, "Membentuk Karakter Melalui Pendidikan Berbasis Nilai. Jurnal Al-Ulum Volume. 13 Nomor 1, Juni 2013, hal. 6

${ }^{4}$ Setya Yuwana Sudikan, Metode Penelitian Sastra Lisan, (Surabaya: Citra Wacana, 1993), hal. 
Koentjaraningrat berpendapat bahwa nilai budaya adalah tingkat pertama dan paling abstrak dari adat. Tingkat ini adalah ide-ide yang mengkonsepsikan halhal yang paling bernilai dalam kehidupan bermasyarakat ${ }^{5}$. Oleh sebab itu dapat dikatakan bahwa seluruh pengetahuan manusia yang diyakini kebenarannya oleh suatu masyarakat tertentu menjadi sumber dan dasar untuk menilai. Adapun penilain yang dimaksud dapat berupa penilaian baik atau buruk, berharga atau tidak dan seterusnya. Nilai budaya juga dapat bersumber dari pandangan hidup dari kode etik yang dimiliki setiap manusia di dunia ini.

Sebagai sebuah produk budaya yang merupakan hasil karsa, pemikiran dan karya manusia maka tradisi Macapatan merupakan sangat sarat dengan nilainilai. Nilai-nilai yang terkandung dalam tradisi Macapatan merupakan nilai yang mewarnai kehidupan manusia seperti nilai ketoleransian, nilai kerukunan, nilai kebersamaan dan sebagainya.

\section{B. Sejarah, Makna dan Tujuan Tradisi Macapatan}

Dalam Mbombong Manah Tejdohadisumarto, disebutkan bahwa tembang macapat (yang mencakup 11 metrum ) diciptakan oleh Prabu Dewawasesa atau Prabu Banjaran Sari di Sigaluh pada tahun 1191 Jawa (1279 Masehi) ${ }^{6}$. Tetapi menurut sumber lain, tampaknya macapat tidak hanya diciptakan oleh satu orang, tetapi oleh beberapa orang wali dan bangsawan?

Para pencipta itu adalah Sunan Giri Kedaton, Sunan Giri Prapen, Sunan Bonang, Sunan Gunung Jati, Sunan Muryapada, Sunan Kali Jaga, Sunan Drajat, Sunan Kudus, Sunan Geseng, Sunan Majagung, Sultan Pajang, Sultan Adi Eru Cakra, dan Adipati Nata Praja.

Jika ditilik melalui sejarah, tradisi Macapatan sudah ada sejak zaman Majapahit ${ }^{8}$, namun pendapat tersebut ada yang mengatakan tidak shahih karena sebagian berpendapat lagi bahwa tradisi yang ada pada zaman tersebut adalah kidung. Namun tidak dapat dipungkiri bahwa tradisi Macapatan sudah ada sejak 1500 SM. Pada saat itu masyarakat Jawa masih menganut kepercayaan Animisme dan Dinamisme.

\footnotetext{
${ }^{5}$ Koentjaraningrat, Metode-metode Penelitian Masyarakat. (Jakarta: PT. Gramedia. Pustaka Utama, 1993), hal. 192

${ }^{6}$ Tejdohadisumarto, Mbombong Manah. (Djakarta: Djambatan, 1985), hal. . 5

${ }^{7}$ Laginem (et al ), hal. Macapat Tradisional dalam Bahasa Jawa. (Jakarta : Pusat Pembinaan dan Pengembangan Bahasa, 1996), hal. . 27

${ }^{8}$ Sastrasoepadma, Kesustraan Djawa, (Yogyakarta: Sujadi, 1954), hal. 15
} 
Munculnya tradisi Macapatan merupakan keberlanjutan dari tradisi Kidung, sehingga diakhir perkembangannya muncul dan tumbuh dengan pesat sastra suluk yang masih mindstream Macapatan ${ }^{9}$. Namun, pendapat tentang munculnya Macapatan masih menjadi perdebatan yang cukup panjang. beberapa pendapat mengatakan bahwa Macapatan muncul pada masa kerajaan Demak, kemudian berkembang sangat pesat pada saat kerjaan Pajang di Mataram, Surakarta, dan Yogyakarta. Sastrawan Macapatan terakhir dan yang masih menggunakan Macapatan sebagai tembang kesustraan adalah R.Ng Ranggawarsita.

Perbedaan pendapat tentang muncul dan berkembanganya tradisi Macapat atau Macapatan merupakan kewajaran. Sebab arti kata dari "Macapat" semula adalah bergerombol atau berkumpul sambil menyuarakan dan melantunkan pujipujian. Asal kata arti tersebut adalah dari jarwa dhosok, yang berarti ma mempunyai arti menuju dan capet yang artinya maya atau ghaib. Jika digabung arti tersebut artinya adalah "puji-pujian kepada tuhan".

Tradisi Macapatan merupakan salah satu yang masih sering dijumpai di daerah yang masih meyakini adat istiadat leluhur ${ }^{10}$. Dengan tujuan agar lebih mendekatkan seseorang kepada leluhurnya. Selain itu, dimaksudkan untuk memberi ajaran kepada keturunan agar memiliki prilaku yang utama, yaitu sikap dan tatakelakuan yang didasari budi luhur dan berpegang teguh pada ajaran agama Islam seperti yang dilakukan oleh seorang tokoh masyarakat atau orang-orang terdahulu yang dapat dijadikan panutan dan tuntunan.

Dalam pandangan penulis, tradisi Macapat atau Macapatan adalah sebuah tradisi pembacaan atau membacakan naskah Macapat atau puisi tradisional yang dibacakan oleh seorang yang ahli membaca kitab, buku, atau sastra Macapat. Sesuai dengan namanya naskah yang dibaca pada tradisi ini adalah naskah yang kental dengan nilai-nilai keagamaan Islam dan kehidupan manusia sebagai hamba Allah. Tentu saja dengan membaca naskah Macapat maka si pendengar dan pembaca macapat secara langsung maupun tidak langsung mereka belajar tentang keislaman. Salah satu contoh naskah macapat cerita tentang Nabi Musa yang menjalankan misi dakwahnya, beliau berdoa dalam QS Thoha ayat 25, 26, 27, dan 28 yang artinya " ya tuhanku lapanganlah untukku di dadaku dan mudahkanlah untukku urusanku dan lepaskanlah kekuatanku dari lidahku supaya mereka mengerti perkataanku.

9Jumiran, Inovasi Tembang Jawa. (Malang: Makalah KBJIL, 1996), hal.

10Wellek, Renne Dan Austin Warren, Teori Kesusastraan; Diterjemahkan Oleh Melani Budianta (Jakarta: Gramedia, 1995), hal. 26-27 
Dapat dijelaskan pula tradisi Macapatan adalah suatu tradisi yang dilakukan oleh masyarakat yang mempercayai tentang ajaran prilaku yang baik yang digambarkan di dalam buku karangan leluhur zaman dahulu yang sampai sekarang masih dipercaya dan dikenal dengan sebutan buku "pat" Sindujoyo. Kridalaksana berpendapat peran unsur dalam suatu ajaran secara struktural dengan unsur lain dalam kehidupan sosial, manusia merupakan salah satu unsur yang paling penting dan selalu mengadakan hubungan sosial ${ }^{11}$. Proses kehidupan sosial manusia bukan unetuk memenuhi kebutuhan individu, tetapi juga mempertaharankan struktur sosial.

Penjelasan tersebut dapat diperjelas dengan penjelasan yang ada dalam kamus bahasa Indonesi berarti "daya yang ada atau yang timbul dari diri manusia yang membentuk perwatakan, kepercayaan atau perbuatan seseorang". Jadi dapat dijelaskan bahwa tradisi Macapatan merupakan suatu daya yang timbul dari teks Macapat yang ikut membentuk watak, kepercayaan, dan prilaku manusia yang ada disekitarnya.

Keberhasilan seorang tokoh masyarakat dalam melaksanakan amalan dengan membacakan kidungan yang setelah itu diartikan dengan maksud pembacaan naskah Macapatan atau tradisi Macapatan adalah agar generasi berikutnya atau keturunannya agar dapat mencontoh prilaku baik yang telah dicontohkan dan dilakukan oleh orang-orang terhadulu atau nenek moyangnya.

Zuhairini berpendapat prinsipnya metode yang digunakan ketika Macapatan ketika seorang tokoh menyampaikan isi kitab Macapat yaitu menggunakan metode membaca, cermah dan tanya jawab ${ }^{12}$. Atau kolaboratif antara ketiganya. Menurut hemat penulis cara penyampaian kitab Macapat kepada para penikmatnya merupakan suatu yang penting karena agar mudah dimengerti oleh pendengarnya. Tradisi Macapatan dilaksanakan saat-saat tertentu, yaitu pada saat pelaksanaan haul, pesta rakyat, pada malam acara pernikahan dan sebagainya.

\section{Tradisi Macapatan Sebagai Transmisi Nilai Moral}

Semua sistem religi, kepercayaan dan agama di dunia menurut berpusat pada suatu konsep pada hal-hal gaib yang dianggap sangat dahsyat dan keramat

11 Harimurti Kridalaksana, Kamus Linguistik (Jakarta: PT. Gramedia, 1996), hal. . Nasional, 1983), hal. 82

12 Zuhairini, dkk, Metodik Pendidikan Bahasa Indonesia. (Surabaya: Usaha 
oleh manusia ${ }^{13}$. Sifat dari hal-hal yang gaib yang dianggap sangat dahsyat dan keramat itu adalah maha abadi, maha dahsyat, maha baik, maha adil, tidak terlihat dan tidak mungkin dapat dicakup oleh pikiran dan akal manusia.

Menurut kepercayaan masyarakat Jawa, makhluk halus dapat mendatangkan kesuksesan, kebahagiaan, ketentraman, ataupun keselamatan. Tetapi sebaliknya makhluk halus juga dipercaya gangguan pikiran kesehatan bahkan kematian. Jadi apabila ingin hidup tanpa menderita gangguan itu, ia harus berbuat sesuatu untuk mempengaruhi alam. Misalnya dengan berprihatin, berpuasa, berpantang melakukan sesuatu, berpantang memakan makanan tertentu, berselamatan dan bersaji. Cara-cara seperti itu sering dijalankan oleh masyarakat Jawa di waktu tertentu dalam peristiwa sehari-hari ${ }^{14}$.

Prilaku manusia merupakan aktivitas manusia yang nampak, prilaku atau aktivitas tersebut dalam pengertian yang luas, yaitu prilaku yang menampak (overt behaviori) dan atau prilaku yang tidak menampak (mert behavior), demikian pula aktivitas-aktivitas motoris juga termasuk aktivitas emosional dan kognitif. Sebagaimana diketahui prilaku atau aktivitas yang ada pada individu atau organisme itu tidak timbul dengan sendirinya, tetapi sebagai akibat dari stimulus yang diterima oleh organisme yang bersangkutan baik stimulus eksternal maupun stimulus internal. Bagaimana cara membentuk prilaku itu sesuai dengan yang diharapkan. Diantaranya Metode yang dpakai dalam pembentukan prilaku:

\section{a. Pembentukan Prilaku dengan Cara Condisioning atau Pembiasaan}

Salah satu cara pembentukan prilaku dapat ditempuh dengan kebiasaan. Dengan cara ini membiasakan diri dengan berprilaku seperti yang diharapkan, akhirnya akan terbentuklah prilaku tersebut. Misalnya dibiasakan bangun pagi, mengucapkan terimakasih bila diberih sesuatu oleh orang lain, membiasakan sholat tepat pada waktunya. Cara ini didasarkan atas asasteori belajar condisioning.

\section{b. Pembentukan Prilaku dengan Pengertian (insting)}

Di samping pembentukan prilaku dengan condisioning atau cara kebiasaan, pembentukan prilaku dapat di bentuk dengan pengertian (insting). Misalnya datang sekolah jangan terlambat, karena prilaku tersebut dapat mengganggu orang lain. Cara ini berdasarkan atas teori belajar kognitif, yaitu belajar dengan cara diserati pengertian.

${ }^{13 K}$ Koentjaraningrat, Prilaku Masyarakat Pesisir (Jakarta: Djambatan, 1985), hal. ${ }^{14} \mathrm{lbid}$., hal. 340 


\section{c. Pembentukan Prilaku dengan Cara Model}

Pembentukan prilaku dapat ditempuh dengan menggunakan model atau contoh. Kalau orang bicara bahwa orangtua sebagai contoh anak-anaknya, pemimpin sebagai panutan yang di pimpinannya, seorang tokoh yang digemari jadi panutan. Cara ini didasarkan atas teori belajar sosial (social Learning Theory) atau observational learning theory yang dikemukakan oleh Bandura (1977).

\section{d. Macam-Macam Teori Prilaku}

Prilaku manusia tidak dapat lepas dari keadaan individu ini sendiri dan lingkungan dimana individu itu berada. Prilaku manusia itu didorong oleh motif tertentu sehingga manusia itu berprilaku. Beberapa teori yang berkaitan dengan prilaku adalah:

1) Teori Insting

Teori ini dikemukakan oleh Mc Dougall sebagai pelopor dari sosiologi sosial, yang menyatakan bahwa, prilaku ini di sebabkan karena insting. Insting maerpakan prilaku yang innat, prilaku yang bawaan dan insting akan mengalami perubahan karena pengalaman. Pendapat ini menjelaskan bahwa prilaku manusia itu di sebabkan karena banyak faktor termasuk orang-orang yang ada disekitarnya dengan prilakunya.

2) Teori dorongan (Drive Theory)

Menurut Hull (1983) yang menyatan bahwa Teori ini bertitik tolak pada pandangan bahwa organisme itu mempunyai dorongan-dorongan atau drive tertentu. dorongan-dorongan ini berkaitan dengan kebutujan-kebutuhan organisme yang mendorong organisme untuk berprilaku. Apabila organisme mempuyai kebutuhan, maka akan terjadi ketegangan dalam organisme tertentu

3) Teori Insentif

Menurut Hull (1983) bahwa Teori ini bertitik tolak pada pendapat bahwa prilaku organisme itu disebabkan karena adanya insentif, dengan teori ini maka akan mendorong seseorang untuk berprilaku atau berbuat sesuatu. Hal ini di sebabkan karena adanya prilaku yang berbeda-beda pada dir manusia.

4) Teori Atribusi

Teori ini menjelaskan tentang sebab-sebab prilaku orang apakah prilaku ini itu disebabkan oleh disposisi internal misalnya motif, sikap dan lain-lain ataukah oleh keadaan eksternal. Teori ini dikemukakan oleh Fritz Heider. Pada 
dasarnya prilaku manusia itu dapat atribusi internal tetapi juga dapat atribusi eksternal.

Mengacu pada keterangan-keterangan di atas tentang tradisi Macapatan yang dengan prilaku manusia, bahwa nilai budaya yang berbentuk tradisi tersebut merupakan konsep-konsep mengenai apa yang hidup dalam pikiran. Sehingga kebanyakan masyarakat dianggap bernilai, beradab, atau tindakan bermartabat yang sesuai dengan budaya yang hidup di daerah tersebut. Nilai budaya tersebut yang ada seperti itulah sehingga dapat dimanfaatkan sebagai pedoman untuk memberikan arah dan tuntunan untuk memberikan kehidupan masyarakat sebagai makhluk sosial.

\section{Pengaruh Tradisi Macapatan Terhadap Perilaku Masyarakat}

Berdasarkan hasil penelitian yang dilakukan oleh peneliti maka dapat diuraikan bahwa kesenian Macapat Sindujoyo adalah bentuk kesenian pembacaan naskah kuno Macapat Sindujoyo, yang menceritakan tentang perjalanan hidup seorang tokoh, yang mana tokoh tersebut bernama Sindujoyo. Macapat Sindujoyo merupakan kesenian yang masih sering ditemui di kelurahan lumpur kecamatan Gresik. Maksud dari pembacaan Macapat Sindujoyo tersebut agar keturunan Sindujoyo mengenal dan memiliki prilaku yang utama. Sikap dan prilaku yang utama tersebut berupa sikap dan tata kelakuan yang didasari oleh budi luhur yang berpegang teguh pada ajaran agama Islam seperti yang dilakukan oleh tokoh utama tersebut yaitu Sindujoyo.

Tradisi Macapat Sindujoyo telah berjalan sejak zaman dahulu yang dibaca oleh Bapak Ridwan yang lahir kira-kira tahun 1929, dikelurahan Lumpur Gresik kecamatan Gresik Kabupaten Gresik. Tradisi Macapat Sindujoyo masih sangat eksis meskipun telah mengalami pergantian pembaca utamanya. Pada saat ini pembaca utama adalah Nur Ngaidi, yang sebelumnya adalah Bapak Ridwan.

Tradisi Macapat Sindujoyo dilaksanakan pada saat tertentu seperti saat acara haul Sindujoyo, perkawinan, sunatan dan acara-acara lainnya. Pelaksanaan tradisi Macapat untuk pernikahan dan sunatan berdasarkan permintaan saja. Sedangkan pada saat haul Sindujoyo Macapat wajib dibaca, dengan durasi waktu satu hari satu malam. Tradisi membaca Macapat saat haul Sindujoyo bersifat wajib dan membacanya pun tidak selesai dalam satu hari saja, namun dilanjutkan hari berikutnya. 
Menurut Nur Ngaidi (sesepuh atau tokoh pembaca Mancapat Sindujoyo) pada saat pernikahan pembacaan Macapat di baca secara lisan. Pembaca dan pendengar duduk bersamaan dan membaca Macapat (bukan naskah Asli) hasil penggandaa. Hal ini dilakukan karena naskah Macapat yang asli kondisinya sudah mulai rusak selain itu naskah asli dianggap sakral sehingga tidak pernah dikeluarkan dari tempatnya yaitu di makam Dalem Kelurahan karangpoh Kecamatan Gresik Kabupaten Gresik. Biasanya membaca naskah Macapat tidak dapat diselesaikan dalam waktu satu hari satu malam oleh sebab itu membutuhkan waktu dua hingga tiga hari untuk membacanya.

Berdasarkan hasil penelitian yang dilakukan oleh peneliti saat pelaksanaan Macapatan Sindujoyo. Pelaksanaan Macapatan Sindujoyo berlagsung dengan khidmat dan pendengar telihat sangat antusia mendengarkan bagian-bagian cerita macapat yang dibacakan oleh Nur Nagidi. Tidak ada seragam khusus maupun atribut khusus yang melekat para pendengar Macapat. Oleh sebab itu, berangkat dari kesederhanaan tersebut tradisi Macapat Sindujoyo dapat dinikmati oleh seluruh palisan masyarakat, tanpa mengenal usia, jabatan, pangkat ataupun yang lainnya.

Menurut beberapa sumber bahwa pembaca buku/kitab Macapat Sindujoyo sampai saat ini hanya bisa dilakukan oleh orang-orang tertentu, yang memang ahli dibidang membaca Macapat. Satu tokoh sentral pembaca Macapat Sindujoyo adalah Nur Ngaidi. Tugas utama si pembaca adalah menyampaikan isi Macapat dan menjelaskan maksud dan tujuan isinya tersebut. Justru penyampainnya tersebut harus udah dimengerti oleh seluruh Masyarakat. Selain haul Sindujoyo, tradisi Macapatan ini boleh dibaca saat-saat tertentu misalnya saat khitanan dan perkawinan atau sesuai permintaan Si Pemilik Hajat.

Pendengar merupakan unsur penting dalam tradisi Macapatan Sindujoyo. Sebagai satu seni pembacaan Macapat, tradisi ini dianggap tidak berguna atau kurang kemanfaatannya jika tanpa adanya pendengar. Tradisi Macapatan Sindujoyo merupakan merupakan suatu seni tradisional yang pada umumnya dianggap telah ketinggalan zaman, tetapi masih mempunyai pendengar yang cukup banyak. Setiap diselenggarakan tradisi Macapat, peserta atau pendengarnya kurang lebih 50 -75 pendengar.

Pendengar macapatan sangat antusias dan fokus mendengarkan tiap-tiap bait Macapat yang dibacakan. Demikian juga dengan pendengarnya dari semua golongan dan tidak membeda-bedakan. Khusus di wilayah Sindujoyo pendengar 
Macapat adalah mereka yang berprofesi sebagai nelayan dan pedagang (karena dominasi Penduduk Sindujoyo adalah nelayan dan pedagang). Salah satu responden berpendapat bahwa tradisi Macapat sangat menarik dan merupakan wadah atau media lain dalam mencari ilmu dan sebagai wadah bersosialisasi antar masyarakat.

Berdasarkan temuan di lapangan tradisi Macapatan ini dilaksanakan dengan menggunakan tenda atau cukup di teras rumah warga. Namun, khusus ketika haul Sindujoyo maka maka pelaksanaannya di balai (tempat peristirahatan nelayan Sindujoyo). Tradisi ini masih mengusung keserhanaan dalam pelaksanaannya, ini terlihat atribut yang digunakan saat kegiatan ini berlangsung yaitu cukup dengan beralaskan tikar atau karpet yang dilengkapi dengan meja kecil untuk pembaca.

Adapun pelaksanaannya saat haul yaitu pada bulan Sahafar tahun hijriyah, disesuaikan dengan tanggal dan tahun wafatnya sesepuh Sindujoyo. Sindujoyo merupakan sesepuh yang dihormati dan kharismatik oleh masyarakat kelurahan Lumpur. Sehingga tahun dan tanggal wafatnya diperingati oleh masyarakat setempat (Sindujoyo). Salah satu rangkaian kegiatan yang dilaksanakan saat haul adalah membaca Macapat.

\section{Pengaruh Tradisi Macapatan Sindujoyo terhadap Prilaku Masyarakat Melalui Isi Cerita}

Berdasarkan pengamatan dan responden dapat dianalisis bahwa cerita naskah Sindujoyo yang telah dibacakan pembaca Macapat Sindujoyo ternyata dapat mempengaruhi kepercayaan atau prilaku masyarakat. Ini dapat dibuktikan dengan temuan bahwa ada pantangan masyarakat keluraha Lumpur menikahi gadis yang berasal dari desa Gumeno Gresik. Sumber ini dapat dilihat dari cerita-cerita yang ada di Macapat Sindujoyo. Secara historisnya kepercayaan tersebut bermula ketika Sindujoyo berbuat kesalahan terhadap seorang wanita dari Gumeno Gresik. Sindjoyo dengan tidak sengaja telah membunuh istri Kidang Paling (panglima perang desa Gumeno Gresik).

Setelah panglima tersebut dikalahkan Sindujoyo, istrinya tidak berniat membalas kematian suaminya dengan berperang melawan Sindujoyo. Pada saat berperang tersebut istri Kidang Paling berpakaian seperti layaknya seorang laki-laki. Perlengkapan laki-laki dipakainya dari ujung rambut sampai ujung kaki. Sehingga Sindujoyo tidak mengetahui bahwa lawannya adalah seorang wanita. Akhirnya dengan mudahnya Sindujoyo dapat mengalahkan istri 
Kidang Paling dan berhasil membunuhnya. Alangkah terkejutnya begitu menyadari bahwa orang yang dibunuhnya adalah seorang wanita setelah terlihat betisnya. Sindujoyo pun sangat menyesal, kemudian segera mengambil air wudhu dan melaksanakan shalat dan memohon ampun kepada Allah SWT.

Peristiwa tersebut menimbulkan sikap bahwa masyarakat kelurahan Lumpur Gresik (terutama yang laki-laki/perjaka) tidak berani atau lebih tepatnya pantangan menikah dengan gadis asal desa Gumeno Gresik. Jika hal tersebut dilanggar, kepercayaan masyarakat menganggap bahwa kehidupan rumah tangga mereka kelak akan gagal di tengah perjalanan (tidak sakinah). Keprcayaan tersebut berlaku dan dipercayai oleh masyarakat Sindujoyo sampai sekarang.

Berdasarkan hasil wawancara dengan responden bapak Shobirin dapat diskripsikan, bahwa jika dilanggar kepercayaan tersebut maka peristiwa serupapun akan menimpah (jawa: balak) orang yang melanggarnya tersebut. Tidak hanya itu, sanksi sosial juga diterapkan bagi siapa saja yang melanggar. Biasanya bagi para pelanggar kepercayaan tersebut dengan sendirinya akan merasa malu dan tidak mau tinggal di daerah kelurahan Lumpur kecamatan Gresik Kabupaten Gresik.

\section{Pengaruh Tradisi Macapatan Sindujoyo terhadap Masyarakat Melalui} Tokoh Sindujoyo

Berdasarkan pengamatan peneliti bahwa tokoh Sindujoyo mempunyai pesyarakat yang ada pengaruh yang sangat kuat terhadap prilaku masyarakat kelurahan Lumpur Gresik kecamatan Gresik kabupaten Gresik. Pengaruh tersebut baik berupa pengabadian nama Sindujoyo yang digunakan sebagai nama tempat, nama kepercayaan, dan tindakan masyarakat yanb masih ada kaitannya dengan ketokohan Sindujoyo.

\section{Tanggapan Masyarakat Lumpur terhadap Tradisi Macapatan Sindujoyo}

Tradisi Macapatan Sindujoyo merupakan seni yang amat sederhana dan masih mendapat simpati dari masyarakat pedukungnya. Balai tempat diselenggarakan tradisi Macapatan selalu dipenuhi oleh pendengar setianya. Hal tersebut sebagai tanda bahwa tradisi Macapatan Sindujoyo masih diminati oleh masyarakat. Para pendengar tradisi Macapatan Sindujoyo berasal dari golongan bawah, menengah, dan golongan atas. Namun pada umumnya yang menjadi pendengar tradisi Macapatan Sindujoyo berasal dari bawah dan menengah yang berprofesi sebagai nelayan dan pedagang. 
Pendengar setia kesenian Macapatan Sindujoyo dalah pemuda dan orang dewasa. Sebagai pendengar setia mereka sangat antusia saat Macapatan berlangung dan bahkan mereka mengikuti tradisi Macapatan hingga selesai di akhir ceritanya. Adapun hidangan pendamping Macapatan berupa kue dan kopi. Pendengar setia Macapatan mempunyai tanggapan cukup baik terhadap tradisi Macapatan Sindujoyo. Salah satu responden berpendapat bahwa para pecinta Macapat sangat senang dan terhibur dengan tradisi yang Macapat tersebut dan menjadi salah satu hiburan yang ditunggu oleh masyarakat khususnya masyarakat Sindujoyo. Selain itu, menyimak Macapat sama dengan belajar tentang hidup dan kehidupan, sebagai sarana untuk bersilaturrahim antar sesama warga.

Dalam proses penganalisaan ini, penulis menggunakan rumus statistik dengan tujuanan untuk menguji diterima atau ditolaknya hypotesa (kesimpulan sementara) yang diajukan. Dalam menganalisa data, penulis memberi rincian sebagai berikut: mencari pengaruhnya tradisi Macapatan Sindujoyo dengan perubahan prilaku masyarakat di Lumpur Gresik kecamatan Gresik Kabupaten Gresik.

Dari hasil data angket yang disebar kepada 100 responden maka dapat dijabarkan bahwa pengetahuan masyarakat tentang tradisi Macapat dengan jumlah responden 34 dengan keterangan tinggi, untuk keterangan sedang ada 60 responden, untuk keterangan rendah 6 responden. Analiasa tersebut menunjukkan bahwa masyarakat Lumpur pada taraf sedang dalam memahami tradisi Macapat. Berdasarkan analisa Chi Kuadrat dari 100 responden, maka perhitungan menyatakan nilai Chi Kuadrat adalah 3,8. Sedangkan hipotesa kerjanya yang berbunyi "ada pengaruh antara pengetahuan masyarakat tentang tradisi Macapatan dengan perubahan prilaku setelah pengikutnya.

Sedangkan untuk mengetahui besar/kecilnya pengaruh tersebut, maka nilai Chi Kuadrat hasil perhitungan tersebut maka dilakukan tes dengan rumus Koefisien Kontigensi (KK). Maka dari cara tersebut dapat diperoleh hasil akhir yaitu 0,189 yang berarti merupakan suatu angka yang berada diantara 0,000 sampai dengan 0,200 dengan demikian berarti pengaruh tradisi Macapatan Sindujoyo terhadap prilaku masyarakat Lumpur Gresik adalah pengaruh sangat rendah. 
Adapun nilai angket dan kategorisasi prilaku masyarakat Lumpur, setelah mengikuti tradisi Macapatan dapat dianalisis, bahwa prilaku yang baik sebanyak 3 masyarakat dengan prosentase 3\%, prilaku cukup sebanyak 83 masyarakat dengan prosentase 83\%, dan prilaku yang kurang sebanyak 14 masyarakat dengan prosentase $14 \%$. Sedangkan nilai angket dan kategorisasi pengetahuan tentang Macapatan Sindujoyo di Lumpur Gresik.

\begin{tabular}{|c|c|c|c|}
\hline $\begin{array}{c}\text { Pengetahuan tentang } \\
\text { tradisi Macapatan }\end{array}$ & Prilaku masyarakat & Jumlah & Prosentase \\
\hline Tinggi & Baik & 0 & $0 \%$ \\
& Cukup & 27 & $27 \%$ \\
& Kurang & 7 & $7 \%$ \\
\hline Sedang & Baik & 3 & $3 \%$ \\
& Cukup & 51 & $51 \%$ \\
& Kurang & 6 & $6 \%$ \\
\hline Rendah & Baik & 0 & $0 \%$ \\
& Cukup & 5 & $5 \%$ \\
& Kurang & 1 & $1 \%$ \\
\hline & Jumlah & $\mathbf{1 0 0}$ & $\mathbf{1 0 0} \%$ \\
\hline
\end{tabular}

\section{E. PENUTUP}

Tradisi Macapatan Sindujoyo banyak mengandung nilai budaya yang dapat dijadikan pedoman dan tuntunan hidup yang baik bagi yang mengikutinya dilingkungan masyarakat lumpur kecamatan Gresik kabupaten Gresik. Selain itu tradisi Macapatan Sindujoyo juga berfungsi sebagai pengaruh dan pendorong seseorang dalam melakukan perbuatan.

Dilihat dari hasil analisa data dapat disimpulkan bahwa pengaruh tradisi Macapatan Sindujoyo terhadap perubahan prilaku masyarakat Lumpur sangat rendah. Pernyataan tersebut dibuktikan dari hasil Koefisin Kontigensi (KK) yaitu 0,189 . Penyebabnya adalah kurang fahamnya pendengar makna tradisi Macapatan dan kurang antusiasnya para pendengar ketika menghadiri Macapatan. 


\section{DAFTAR PUSTAKA}

Koentjaraningrat, 1995. Prilaku Masyarakat Pesisir, Jakarta: Djambatan.

Arikunto, Suharsimi, 1998. Prosuder Penelitian Suatu Pendekatan Praktek. Jakarta: PT. Rineka Cipta.

Jumira, Inovasi Tembang Jawa. Malang: Makalah KBJIL

Koentjaraningrat, 1993. Metode-metode Penelitian Masyarakat. Jakarta, PT. Gramedia Pustaka Utama.

Kridalaksana, Harimurti, 1992. Kamus Linguistik, Jakarta: PT. Gramedia.

Laginem (et al ), 1996. Macapat Tradisional Dalam Bahasa Jawa. Jakarta : Pusat Pembinaan dan Pengembangan Bahasa.

Sastrasoepadma, 1994. Kesustraan Djawa. Yogyakarta:Sujadi.

Sudikan, Setya Yuwana. 1994. Metode Penelitian Sastra Lisan. Surabaya: Citra Wacana.

Tejdohadisumartom . 1985. Mbombong Manah. Djakarta: Djambatan.

Wellek, Renne dan Austin Warren, 1985. Teori Kesusastraan (Diterjemahkan Oleh Melani Budianta). Jakarta: Gramedia.

Yusuf, Muhammad, "Membentuk Karakter Melalui Pendidikan Berbasis Nilai”, jurnal AlUlum Volume. 13 Nomor 1, Juni 2013

Zuhairini, dkk, 1983. Metodik Pendidikan Bahasa Indonesia. Surabaya: Usaha Nasional. 